\title{
Parental Choice and Learner Achievement in Primary Education in Rachuonyo Sub County, Kenya: Focusing on Quality of Education
}

\author{
Charles Richard Oyier ${ }^{1}$, Paul Amollo Odundo ${ }^{1, *}$, Rispa Atieno Obat ${ }^{2}$, Ganira Khavugwi Lilian ${ }^{1} \&$ Joseph Ochieng \\ Akondo $^{1}$ \\ ${ }^{1}$ Department of Educational Communication and Technology, University of Nairobi, Kenya \\ ${ }^{2}$ Nyatwere Primary School, Homabay, Kenya \\ *Corresponding author: Department of Educational Communication and Technology, University of Nairobi, P. O. \\ Box 30197 - 00100, GPO, Nairobi, Kenya. E-mail: odundopaul@yahoo.com
}

Received: July 9, $2015 \quad$ Accepted: September 3, $2015 \quad$ Online Published: October 15, 2015

doi:10.5430/wje.v5n5p130 URL: http://dx.doi.org/10.5430/wje.v5n5p130

\begin{abstract}
Kenyan government launched Free Primary Education (FPE) in 2003 to make schooling affordable to all parents, but less attention has been paid to the quality assurance and equity of the education system. Studies have indicated that the FPE policy sacrificed the quality of education and this led to parents avoiding FPE offered in primary schools and take their children to private schools which are considered costly. This study adopted descriptive survey design to as the research design. Rational comprehensive model theory was used which aims at discussing personal factors influencing parental choice for primary education schools in Rachuonyo Sub-County, Homabay County, Kenya. The target population for this study was 5269 parents and 198 head teachers out of which 240 respondents were sampled through stratified random sampling. Questionnaires and interview schedules were used as the main data collection tools. Validity and reliability was ascertained by the internal consistency and piloting. The quantitative data was analyzed using data analysis matrix while the qualitative data was analyzed through thematic analysis. The findings showed that the parents had great interest on healthy environments; school safety, social atmosphere and convenience are greatly considered by parents when making decision on schools for children. The findings of the study are that learning environment, school safety, social atmosphere and convenience all influence parental choice for primary schools in Rachuonyo South Sub County. Learning environment scores a mean of 3.1397; school safety, 3.4525; social atmosphere, 3.0782; and convenience 3.1285.
\end{abstract}

Keywords: parental choice; learning environment; school safety; school social atmosphere; convenience; primary education; learners' achievements

\section{Introduction}

Education provides skills required to achieve economic and social development at individual, communal and societal levels. According to Glennerster, Kremer, Mbiti and Takavarasha (2011), education is one of the most promising paths to realize better, more productive lives and primary drivers of national economic development. To achieve this Kenya, at independence viewed education as having a direct relationship with economic growth at national and family levels (UNESCO, 2011). Education was seen as a tool of meeting human resource requirements for a rapidly changing and more diverse economy. To parents education is a productive investment towards creation of a higher standard of living and improved quality of life, implication for choice. Acknowledging that parents need to make a choice, Walker and Clark (2010) noted that extent of one's education, determines difference between success and failure in life, poverty and affluence and generally the quality of life of an individual. Based on this parents hardly handle carelessly issues of education and have to make appropriate choice on schooling for their children. This view is influenced by human capital theory which led to increased enrollments and in turn resulted in more schools being established since independence in Kenya (Oketch, Mutisya, Ngware \& Ezeh, 2010). The choice to take children to school is not uniquely Kenyan, but within the Sub-Saharan Africa (SSA) countries it has led into increase in number of primary schools and in pupil enrolment. In response to rapidly increasing number of children seeking entry for basic education, more schools established, parents are focusing their choice on quality in terms of where to take children for education. Secondly, as the number of schools increased issues of quality standards arose and required 
parents to make decision in choosing school. In acknowledging this Niaz, Rupa and Nazmul (2012) noted that many parents seem to be looking for quality education at whatever cost, regardless of source of provision. In this regard, education has therefore come to occupy a strong position in Kenyan parents' daily life and quite a lot depends on the quality of education which an individual child receives. On the same vein, Glennerster et al (2011) noted that, the citizens and the government of Kenya have invested heavily in improving both access and quality of education, in an effort to realize the promise of education as well as to achieve the education-related Millennium Development Goals, Vision 2030 and middle industrial status.

In exercising choice parents are influenced by a desire to find the optimal school for their children. In an optimal school, parents are not only concerned with academic performance but also personal factors such as the learning environment, school safety, social atmosphere and convenience. Maphosa and Mammen (2011) noted this in a study on the impacts of the universal primary education (UPE) policy on educational attainment in rural South Africa. They found out that as much as parents attached more value to academic performance, personal factors also determine which school they would prefer for their children. In acknowledging that good education is extremely important, Walker and Clark (2010) noted that academic quality is not the only reason for choosing a school. The studies carried out by Maphosa and Mammen (2011) and that of Walker and Clark (2010) were in rural areas, where most parents are in lower socio economic status. In contrary, Dearden, Ryan and Sibieta (2010) found in a comparative study of private schools in United Kingdom and Australia that parents regardless of race or income level put personal values in consideration when choosing schools such as class size, safety, location, and presence of student's friends. This view of Dearden, Ryan and Sibieta (2010) is supported by Oketch and Somerset (2010) quoting Reay and Ball (2007) who in a survey on what the working class parents consider in choosing school for their children in Oxford, England noted that some parents reject the more academic or better, higher reputation schools purely on personal values. This could be what prompted Maphosa and Mammen (2011) to raise questions about the validity of the assumptions underlying market-model approaches to education which strongly favor academic performance. Therefore regardless of income level or socioeconomic status personal factors such as the learning environment, school safety, social atmosphere and convenience are considered by parents.

\subsection{Parental Choice, Learning Environment and Learning Achievement}

Learning environment is the overall situation within the classroom. It ranges from class size, design, construction to available instructional resources. Learning outcomes are dependent not only on class size but also available space in a classroom that would enable adequate interaction between teacher and learners. As noted by Mbiti, (2010) over enrolment experience with introduction of Free Primary Education (FPE) policy in Kenya in 2003 led into increase in class sizes and challenged pedagogy. This pedagogical challenge experienced with introduction of FPE policy in made some parents to opt for private primary schools instead of public ones. A study commission World Bank (2010) found out that in 2000, prior to FPE, the gross enrollment rate in primary school was $87 \%$, but increased to over $100 \%$ in 2003. This surge in enrollment sacrificed quality of education in public schools because of large class sizes. The effect of this was confirmed by Oketch, Mutisya, Ngware and Ezeh (2010) in as study on a comparative analysis on FPE policy in Kenya in which they found that some parents moved their children from public primary schools because of congestion. In summing up as suggested by Dearden, Ryan and Sibieta (2010) parents choose schools with small class size on the premise that they provide better educational quality. The space available in a class is further determined by the design and construction which also influence teaching and learning process; and parental choice of such schools. A well designed class quality and construction positively impact on instructional management. In supporting this position Yi and Chen, (2013) at international forum on creativity education in Shenyang, China noted that the design of learning areas should take into account learners' development needs, provide convenient spaces that will help students to learn. This supports Maphosa and Mammen (2011), who noted that effective use of space and carefully mapped building plans are considered by parents on top of teaching activities to cater for learners' needs and progress. For their part Oketch and Somerset (2010) carefully mapped building plans to establish suitability for catering for learners' needs and could influence parental choice on children schooling.

Availability of instructional resources in a classroom defines suitability of learning environment and has an influence on learners' achievement. According to Oketch, Mutisya and Sagwe (2012), effective teaching requires adequate and appropriate facilities, materials and equipment for students to learn in a classroom. Parents would most likely consider schools adequate instructional resources as they facilitate understanding of abstract concepts. Apart from facilitating understanding of abstract concepts, Oketch, Mutisya and Sagwe (2012) added that availability of instructional materials has a positive correlation on learners' performance. The introduction of FPE over stretched facilities in public schools and especially provision of adequate instructional resources which made parents to opt for 
private instead of public schools (Sarangapani \&Winch, 2010). In a study comparing parents of children in public schools to parents who opted for private ones, Niaz, Rupa and Nazmul (2012) found that parents were most likely to choose schools based on availability of instructional resources because they impact on academic performance and also help in class control. In Kenya a study by Lucas, Adrienne and Mbiti (2010), on school choice under the FPE policy found out that academic competition is seen in private primary schools to attract children because the obsession with examination results that ultimately determines the kind of secondary school a child is likely to attend.

\subsection{Parental Choice, School Safety and Learning Achievement}

School safety embodies another educational priority that parents may consider when making decision on school choice for their children. In fact one of the most important ways in which parents are involved in children's education is through choosing school that is safe. In their study Dearden, Ryan and Sibieta (2010) suggested that parents choose schools for academic reasons and safety. School Safety are measures undertaken by learners, staff, parents and other stakeholders to either minimise or eliminate risky conditions or threats that may cause accidents, bodily injury as well as emotional and psychological distress (Niaz, Rupa \& Nazmul, 2012). A safe and secure school environment facilitates and fosters quality teaching and learning in educational institutions. Safety, especially in schools, is even more critical given the fact that young children are vulnerable to insecurity. In fact, Sarangapani and Winch (2010) identified safety as one of the overriding concerns that parents consider when choosing primary schools for their children. Schools should therefore provide conditions that allow students to study where parents can feel that their children are safe irrespective of their socio-economic status. Oketch and Somerset (2010), noted in a study on demand for primary schooling in Kenya like in Madagascar that children security influences in parental choice between public and private providers.

The Children's Act of 2001, lays emphasis on protection of all children. The school and educational institutions are required to be aware of such rights in order to provide for safeguarding children. Comprehensive school safety is, therefore, fundamental to school success and learner achievement. This was echoed by Lucas, Adrienne and Mbiti (2010) on a study about school choice between public and private primary schools under FPE policy in rural Kenya suggested that parental choice should be looked at beyond academic and children security and comfort in school need to be emphasized. It is important to note that parents prefer schools that perform the core functions of educating children in a safe environment, irrespective of social class. Contrary opinions have been brought forward by different studies, for example Sarangapani and Winch (2010) found that low-income parents preferred that schools perform the core functions of educating children in a safe environment more so than high-income ones. However, this may hold depending on prevailing situations and may differ from one country to another. In Kenya since 2008 unprecedented insecurity is being experienced first from post election violence and secondly due to increasing threat of terror attacks by Al-Shabaab from Somali, various vigilante groups and illegal gangs. Again cases of child abuse that continue to occur, among many other social ills, necessitate keen interest of parents on school safety standards.

\subsection{Parental Choice, Social Atmosphere and Learners Achievements}

School social environment besides academic preference influence some parents when choosing a school for their children. For example, teacher-pupil relationship, discipline and the diversity of the school determine choice by parents. To provide students with a good learning environment, schools should make improvements that allow positive social interactions for sustained cohesiveness. In South Africa, a study by Maphosa and Mammen (2011) on the public/private school choices of low-income households found out that most parents do not feel the need to examine all the alternatives; rather, they wanted to find schools with a strong disciplinary climate and a positive social atmosphere. In the contrary Sarangapani and Winch (2010) suggested that lower-income parents are much less likely to report that school social atmosphere is important consideration when choosing a school for their children. In practice, parents whether with a college education or not are concerned with school social acceptance and teaching values for consideration in deciding children education. Agreeing with this, Oketch and Somerset (2010) argued that parents did not base their choice of school on academic quality alone because disciplinary climate and social atmosphere is equally of importance. Parents also give consideration to teacher-student interactions to which some parents who feel that it is important that every student feel respected. A curriculum design that stresses both intellectual and non-intellectual developments could create a sound educational environment that would impress parents. Yi and Chen, (2013) referring to a case study of Chi-Chiang Elementary School in Taipei, China noted that schools where teacher-student interactions are emphasized and where every learner feels respected easily influence parental choice of school. Agreeing with this, Sarangapani and Winch (2010) noted that by re-creating value of school education, a school could develop specialties by integrating and applying existing facilities, manpower, and community resources in an effective way to bring a positive social atmosphere. On their part Omolo and Simatwa, 
(2010), noted that parents rejected their designated school for reasons associated with social issue and disciplinary climate rather than academic quality.

\subsection{Parental Choice, Convenience and Learners Achievements}

Parents typically choose a school de facto, according to where they live as a convenience when deciding on children's education. In rural Kenyan most schools do not provide transportation to and from the schools, and to parents here convenience includes issues associated with distance to and from school. Those who are most likely to say that location is important are those who are least likely to have resources necessary to sustain daily transportation to and from a faraway school (Omolo and Simatwa, 2010). Pupils attending a school out of immediate environment spend more time on commuting have less time for learning. The more time a pupil spends on school work, the more learning and stronger willingness to acquire more knowledge and studying in a school outside the zone could have negative impact on learning. According to Dearden, Ryan and Sibieta (2010) irrespective of socio-economic status parents consider location an important element in deciding school for their children. School location have an influence on parents decision on schools choice as noted by Johnson and Bowles (2010) in study on middle schools India where majority based their decision on school-home distance. The same was found by Walker and Clark (2010) in a study on parental choice in relation to lifestyle, locality and loyalty. In their study Walker and Clark (2010) telephone-interviewed education superiors in Minnesota's eighty-four school districts and asked reasons why parents chose their school; and found that main consideration was travel distance to school. Supporting this position Oketch, Mutisya, Ngware and Ezeh (2010) in study carried on why are there proportionately more poor pupils enrolled in non-state schools in urban Kenya in spite of FPE policy, showed that transport accessibility was the top consideration for parents when deciding schools for children. In Bangladesh, a study by Asadullah, Niaz and Chaudhury (2010) on the public/private school choices of low-income households found out that most parents do not feel the need to examine all the alternatives; rather, wanted to find the nearest school with a strong disciplinary climate and a positive social atmosphere.

\section{Statement of the Problem}

Despite Kenyan government effort to fund primary education through FPE programme and making it affordable to all parents, some still take their children to private schools which are regarded by others to be costly or prefer specific public schools considered as offering better primary education. Kenyan education system has clear learning outcomes publicized by a uniform examination in which academic performance is much expected to influence parental choice for children education. Less attention has been paid to personal attributes such as learning environment, learners' safety, social atmospheres and convenience could influence parental decision on schools to take children. It was therefore important to look at personal values parents attach to their decisions in choosing schools whether public or private primary for children educations.

\section{The Purpose of the Study}

The purpose of this study was to examine personal factors influencing parental choice for primary schools in Rachuonyo Sub-county in Homabay County, Kenya. Specifically, the study looked at how learning environment, school safety, social atmosphere and convenience guide parents on deciding which primary school to take their children.

\section{Theoretical Framework}

This study considered school choice as decision making process that depends on value attachment as noted by Bagley, Woods and Glatter (2001). In this regard the study adopted Rational Comprehensive Model (RCM), which assumes that the decision maker can identify the problem, has goals, values, and objectives that are clear and ranked in accordance with their importance. In deciding on schools using this models parents' goal is quality education; values are personal attributes such as learning environment, school safety, social atmosphere and convenience; the objectives are learners' achievements. In applying RCM Ashon-Cudjiw (2009) noted that alternative ways of addressing the problem are considered; their cost-benefit analysis or rather advantages and disadvantages are investigated. In this case a parent will consider different schools, compare them in terms of personal attributes and choose the one that maximizes possibility of acquiring quality education (Huisman and Smits, 2009). According to Ashon-Cudjiw (2009), the proponent of RCM was the eminent sociologist Max Weber in 1950 whose concept of rationalization in decision making was based on choices from the factors as core values. 
In employing RCM, the study argues that when parents make decision on choice of school, they attach their decision on some values (Asadullah, Niaz \& Chaudhury, 2010). In this study the personal attributes attached to schools choice considered were learning environment, school safety, social atmosphere and convenience. As theoretical model in public policy decisions all possible options to solving the problem are identified in RCM and the costs and benefits of each option are assessed and compared with each other. The main problem with rational-comprehensive approaches according to Sarangapani and Winch (2010) is that it is often very costly in terms of time and other resources that must be devoted to gathering the relevant information. In their part Niaz, Rupa and Nazmul (2012) argued that often the costs and benefits of the various options are very uncertain and difficult to quantify for rigorous comparison. The costs of undertaking rational-comprehensive decision-making may themselves exceed the benefits to be gained in improved quality of decisions.

\section{Conceptual Framework}

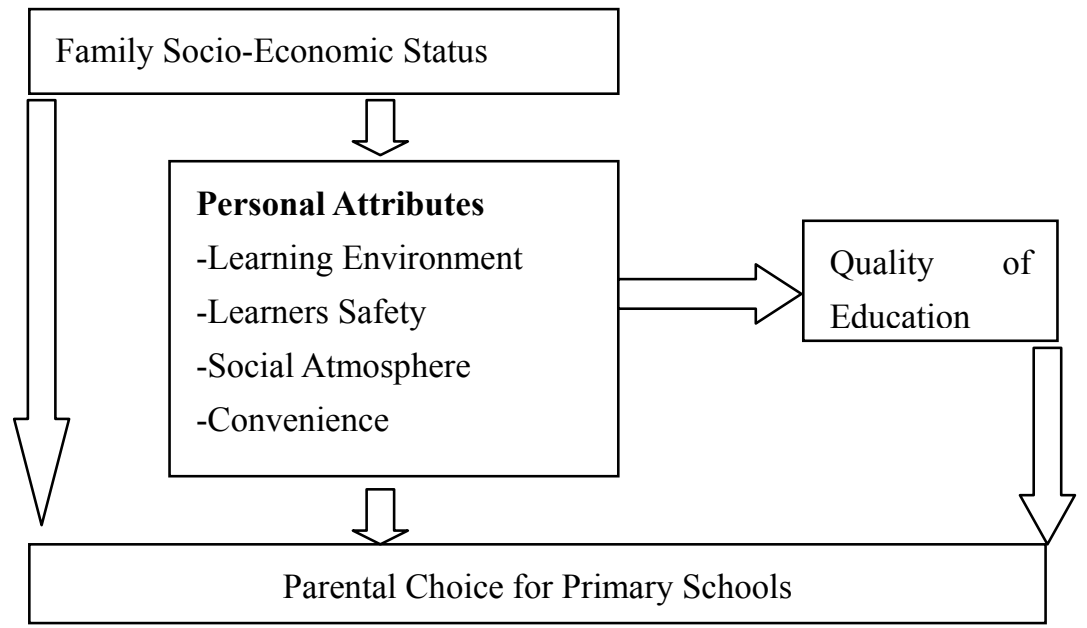

The conceptual framework indicates that family socio-economic status has influence on personal attributes such as learning environment, learners' safety, school social atmosphere and convenience. These personal attributes have a role influence on quality of education children will get from school. Family socio-economic status, personal attributes and the expected quality of education influence parental decision in choosing schools for children.

\section{Methodology}

The study on personal factors influencing parental choice for their children in primary schools in adopted a descriptive survey design. The target population was made up of parents of pupils in class eight from private and public primary schools in Rachuonyo South-Sub County in Homabay County, Kenya. There are 198 primary schools in Rachuonyo South-Sub County out of which, 45 schools are private and 153 are public primary schools. The numbers of class eight pupils in public primary schools were 4597 while those in private were 672 . The study assumed that one parent has one child and this gave the target population to be 5269 parents. In sampling purposive and stratified random sampling techniques were used in which case a ratio of 3:1 was purposively used respectively to drawn the sample from public and private schools. Stratified random sampling was used to ensure inclusion of different categories of schools to give 10 private and 30 public schools resulting into 40 which was about $25 \%$ of the targeted ones as recommended by Asadullah, Niaz and Chaudhury (2010). From each sampled school, 5 parents of class eight pupils were randomly sampled giving a sample size of 200 parents to whom questionnaires were distributed. To ensure validity of the instruments peer consultation was used to adjust and modify both the interview schedule and the questionnaire. For reliability, a pilot study involving 4 schools that were not part of the sample schools was done; two private and two public primary schools were randomly sampled from which parents of two pupils in class 8 were given questionnaires. The pilot study enabled the researcher to familiarize oneself with the administration of the instrument. Split-Half technique of reliability testing was employed, whereby the pilot questionnaires were divided into two equivalent halves and then the Spearman correlation coefficient was computed. A reliability coefficient of 0.7 or greater was accepted which is recommended by Asadullah, Niaz and Chaudhury 
(2010). Before date analysis was undertaken, questionnaires were checked for wrong entries, errors in responses, omissions and other inconsistencies. Open ended questions were grouped into themes or sub-themes then coded. The coding system was incorporated in the Statistical Package for Social Science (SPSS) version 22 data analysis software. Data analysis involved both descriptive and inferential statistics.

\section{Findings and Discussions}

The findings were drawn from 179 parents of out 200 sampled (89.5\%) which was considered adequate enough for analysis.

Table 1. Characteristics of Respondents (in percentages)

\begin{tabular}{|c|c|c|c|c|c|c|c|c|c|c|}
\hline $\begin{array}{l}\text { School } \\
\text { Type }\end{array}$ & $\begin{array}{l}\text { Public } \\
\text { MD }\end{array}$ & 68.9 & $\begin{array}{l}\text { Private } \\
\text { MD }\end{array}$ & 23 & $\begin{array}{l}\text { Public } \\
\text { BB }\end{array}$ & 2.5 & $\begin{array}{l}\text { Private } \\
\text { BB }\end{array}$ & 2.5 & $\begin{array}{l}\text { Private } \\
\text { MB }\end{array}$ & 3.0 \\
\hline $\begin{array}{l}\text { Fathers } \\
\text { Education }\end{array}$ & $\begin{array}{l}\text { Post } \\
\text { Graduate }\end{array}$ & 11.7 & Graduate & 25 & & 14.4 & $\begin{array}{l}\text { Secondary } \\
\text { School }\end{array}$ & 21.1 & & 7.8 \\
\hline $\begin{array}{l}\text { Mothers } \\
\text { Education }\end{array}$ & $\begin{array}{l}\text { Post } \\
\text { Graduate }\end{array}$ & 5.8 & Graduate & 12.7 & & 14.8 & $\begin{array}{l}\text { Secondary } \\
\text { School }\end{array}$ & 19.6 & $\begin{array}{l}\text { Primary } \\
\text { School }\end{array}$ & $\begin{array}{l}21 . \\
7\end{array}$ \\
\hline $\begin{array}{l}\text { Family } \\
\text { Income }\end{array}$ & $\begin{array}{l}\text { Below } \\
10,000\end{array}$ & 17.3 & $\begin{array}{l}10,001-3 \\
0,000\end{array}$ & 33 & $\begin{array}{l}30,001-5 \\
0,000\end{array}$ & 26.8 & $\begin{array}{l}50,001-70 \\
, 000\end{array}$ & 12.3 & $\begin{array}{l}\text { Above } \\
70000\end{array}$ & 9 \\
\hline $\begin{array}{l}\text { Transport } \\
\text { to Schools }\end{array}$ & Walking & 67 & PSV & 16.8 & $\begin{array}{l}\text { Motor } \\
\text { Bike }\end{array}$ & 16.3 & Bicycle & 0 & $\begin{array}{l}\text { School } \\
\text { Bus }\end{array}$ & 0 \\
\hline
\end{tabular}

Key: MD: Mixed Day, BB: Boys Boarding, MB: Mixed Boarding, PSV: Public Service Vehicle

\subsection{Parental Choice and School Types}

In this study primary schools were categorized on the bases of being day or boarding; and single gender or mixed. Parents were asked to state primary school category for their children. Table 1 indicates that, $68.9 \%$ of parents had children in public mixed day primary schools; $23 \%$ in private mixed day; $2.5 \%$ in private boys' boarding; $2.5 \%$ public boys' boarding; and 3.0\% mixed boarding private. The findings shows parents prefer day over boarding schools for children's primary education, totaling $91.9 \%$ out of which $68.9 \%$ are in public and $23 \%$ in private. This is an indication that convenience is a determinant in parental choice for children primary education in Rachuonyo South Sub County. Those with children in private day schools apart from convenience could have considered quality of education offered. This is supported by Oketch, Mutisya, Ngware and Ezeh (2010) assertion that parents seem to be looking for quality education at whatever cost and those who can afford take children to private day schools in Rachuonyo South Sub County.

\subsection{Parental Choice and Educational Levels}

Parents with higher educational attainment are more likely to find themselves in positions where they can make informed decisions on children's education. This study sort the educational level of both parents and according to Table 1 it was found that more fathers have post secondary compared to mothers. It shows that $11.7 \%$ fathers and $5.8 \%$ mothers have post-graduate education; $25 \%$ fathers and $12.7 \%$ mothers are university graduate; $14.4 \%$ fathers and $14.8 \%$ mothers have either college diplomas or certificates. This large number of parents with post secondary education indicates that informed choices about children primary education were made. As noted by Asadullah, Niaz and Chaudhury (2010) empirical evidence consistently demonstrates a positive relationship between parents' education and the likelihood that they would send their children to a private school. The fact that most parents picked day schools for their children in Rachuonyo South Sub County, there was likelihood that higher educational levels had influence on choice of private day schools for convenience and quality. Further analysis according to Table 2 showed that education levels had no significant influence on the school choice because the more educated opted for public mixed day schools. This indicates that private schools in Rachuonyo South Sub County could be offering lower education. 
Table 2. Parental Choice and the Level of Education Cross-tabulation

\begin{tabular}{lcccccc}
\hline School Type & \multicolumn{2}{c}{ Primary Level } & \multicolumn{2}{c}{ Secondary Level } & \multicolumn{2}{c}{ College and University Levels } \\
\cline { 2 - 7 } & Father & Mother & Father & Mother & Father & Mother \\
\hline Public MD & 69 & 18 & 26 & 68 & 29 & 38 \\
Private MD & 12 & 0 & 30 & 42 & 0 & 0 \\
Private BB & 0 & 0 & 4 & 0 & 0 & 4 \\
Public BB & 4 & 4 & 0 & 0 & 0 & 0 \\
Private MB & 0 & 0 & 5 & 0 & 0 & 5 \\
Total & $\mathbf{8 5}$ & $\mathbf{2 2}$ & $\mathbf{6 5}$ & $\mathbf{1 1 0}$ & $\mathbf{2 9}$ & $\mathbf{4 7}$ \\
\hline
\end{tabular}

Key: MD: Mixed Day, BB: Boys Boarding, MB: Mixed Boarding, PSV: Public Service Vehicle

\subsection{Parental Choice and Family Income}

Parents consider education as a productive investment towards creation of a higher standard of living and improved quality of life, implication for choice. Rowley and Goldring (2006) observed that parents with low socioeconomic background give relatively more importance to learning achievement than to student satisfaction with hopes that through education they will break from poverty. In this study parents were asked to give a monthly estimation of family income from various sources. From Table 1, the findings show a normal distribution of income among families in Rachuonyo South Sub County with 17.3\% earning less than Kshs: 10,000 (USD 111), 33\% earn Kshs: 10,001-30,000 (USD 111-333), 26.8\% earn Kshs: 30,001-50,000 (USD 333-777), 12.3\% earn Kshs: 50,001-70,000 (USD 555-777) and 9\% earn above Kshs: 70,000 (USD 777). As already mentioned socio-economic has no significant influence on parental choice in Rachuonyo South Sub County. Contrary to Rowley and Goldring (2006) assertion that parents of low socioeconomic background give relatively more importance to learning achievement, Figure 1 indicates that level of family earnings has no influence on parents' decision on where to take children in Rachuonyo South Sub County

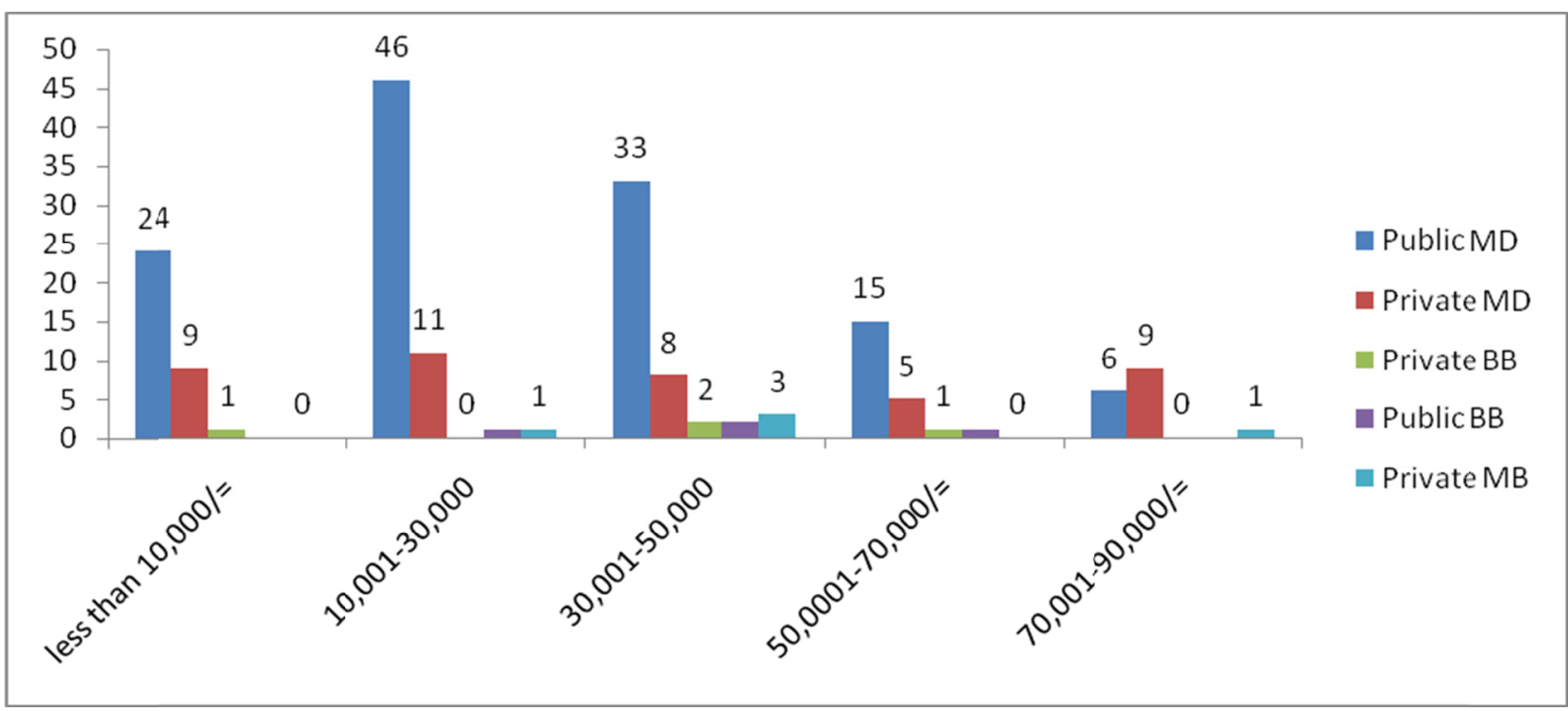

Key: MD: Mixed Day, BB: Boys Boarding, MB: Mixed Boarding, PSV: Public Service Vehicle

Figure 1. Households Monthly Income

\subsection{Parental Choice and Distance to School}

Convenience associated with the distance to and from the school and transportation is priority parents consider when choosing a school for children. In Rachuonyo South Sub County no primary school provides transportation to and from home. Supporting choice of day schools, Table 3 indicates that $67 \%$ (120) of the pupils walk, 16.8\% (30) use public service vehicles and $16.2 \%$ (19) use motor bikes. Results from parents revealed that $74(61.67 \%)$ of those who walk spend less than 10mins to reach school and 46 (38.33\%) take 10-20mins; all those who use PSV and motor bike take less than 10mins to be in school, a further indication that convenience is a determinant in parental choice. This 
was confirmed through interviews of the some head teachers that pupils take an average of $15 \mathrm{mins}$ to get to school walking from their homes. Schools within a sub county are administratively divided into divisions with zones. According to Wango (2011), the number of schools within a zone varies depending on population; in arid semi-arid areas zones could be very big with few schools. Rachuonyo South being a high potential area, zones must be small in sizes but with many schools

Table 3. Parental Choice and Mode of Transportation Cross Tabulation

\begin{tabular}{lcccr}
\hline Type of School & \multicolumn{3}{c}{ Mode of Transportation } & Total \\
\cline { 2 - 4 } & Walking & PSV & Motorbike & 124 \\
\hline Public MD & 70 & 25 & 29 & 42 \\
Private MD & 42 & 0 & 0 & 4 \\
Private BB & 4 & 0 & 0 & 4 \\
Public BB & 4 & 0 & 0 & 5 \\
Private MB & 0 & 5 & 0 & 179 \\
Total & 120 & 30 & 29 & \\
\hline
\end{tabular}

Key: MD: Mixed Day, BB: Boys Boarding, MB: Mixed Boarding, PSV: Public Service Vehicle

\subsection{Parental Choice and Personal Attributes}

This study considered school choice as decision making process that depends on value attachment as noted by Bagley et al., (2001). Using RCM personal attribute such as learning environment, school safety, social atmosphere and convenience were considered as some of values parents attach when deciding schools for children. Parents were asked to rate the extent to which learning environment, school safety, social atmosphere and convenience influence their decision in choosing school for children. They were asked to indicate on a four point scale the extent to which these attributes correctly describe the values they attached to deciding school choice for children in a four-likert scale, (where $1=$ Not at all, $2=$ To a less extent, $3=$ To a moderate extent and $4=$ To a great extent). In analyzing the findings a mean score of 1 or less implies that the factor has no influence on parental choice in deciding schools for children; a mean score above 1 but less than 2 indicates that to a less extent the factor influence parental choice for their children school; a mean score less than 3 but more than 2 suggests that to a moderate extent the factor influence parental choice; and a mean score of above 3 but less than 4 implies that to a great extent it influences parental choice.

Table 4. Parental Choice and Personal Attribute

\begin{tabular}{llll}
\hline Personal Attribute & N & Mean & Std Dev \\
\hline Learning Environment & 179 & 3.1397 & 0.213245 \\
School Safety & 179 & 3.4525 & 0.16586 \\
School Social Atmosphere & 179 & 3.0782 & 0.20604 \\
Convenience & 179 & 3.1285 & 0.252825 \\
\hline
\end{tabular}

\subsubsection{Learning Environment}

Learning outcomes are dependent on class size and available space in a classroom that would enable adequate interaction between teacher and learners. On top of these parents would mostly pick schools with well designed and constructed classrooms, having moderate enrollment and adequate instructional resources all of which constitute the learning environment. Table 4 indicates that learning environment had a mean score of 3.1397 in Rachuonyo South Sub County, showing that it influences parental choice to a great extent. The findings agree Yi and Chen, (2013) who noted that the design of learning areas should take into account the students' development needs, provide convenient spaces that will help students to learn and Maphosa and Mammen (2011), argued that effective use of space and carefully mapped building plans are considered by parents on top of teaching activities to cater for students' needs and progress. Parents believed as reported by Lucas, Adrienne and Mbiti (2010), that overcrowding and heavy teacher workload created stressful working conditions for teachers

\subsubsection{School Safety}

School Safety is an integral and indispensable component of the teaching and learning process. Indeed no meaningful teaching and learning can take place in an environment that is unsafe and insecure to both learners and staff. Safety 
embodies another educational priority that parents may consider when engaging in the school choice process. In fact, Sarangapani and Winch (2010) identified safety as one of the overriding concerns that parents consider when choosing schools for their children. In Rachuonyo South Sub County according to Table 4, school safety had a mean score of 3.4525 an indication that parents considers it to a great extent when choosing children schools. The study findings are in agreement with Oketch and Somerset (2010) who noted that children security is major factor in parental choice between public and private providers, a situation which is great important in Kenya because of threat to terror attack.

\subsubsection{Social Atmosphere}

To provide students with a good learning environment, schools should make improvements that allow positive social interactions for sustained cohesiveness. School social environment besides academic preference influences parental decisions when choosing schools for children. Table 4 indicates that social atmosphere with a mean score of 3.0782 has an influence of parental decision on which schools to take children in Rachuonyo South Sub County. Factors like teacher-student interactions were emphasized by some parents who felt that they were of importance for every student. On their side head teachers agreed that a curriculum design that stresses both intellectual and non-intellectual developments could create a sound educational environment that would impress parents. This is in agreeing Sarangapani and Winch (2010) assertion that by re-creating value of school education, a school could develop specialties by integrating and applying existing facilities, manpower, and community resources in an effective way to bring a positive social atmosphere.

\subsubsection{Convenience}

According Dearden, Ryan and Sibieta (2010), parents choose schools that are convenient with the belief that they will provide better educational quality. They believe that pupils attending a school out of immediate environment spend more time on commuting have less time for learning. In Rachuonyo South Sub County according to Table 4, convenience score a mean of 3.1285, indicating it as a value considered by parents when making choices for schools. This is supported by a position taken by Oketch, Mutisya, Ngware and Ezeh (2010) in study carried in New York that transport accessibility was the top consideration for parents when deciding schools for children.

\section{Conclusion}

Learning environment ranges from class size, design, construction to available instructional resources. Surge in enrollment sacrificed quality of education in public schools because of large class sizes. The reason for this is that learning outcomes are dependent not only on class size but also available space in a classroom that would enable adequate interaction between teacher and learners. Parents choose schools with small class size on the premise that they provide better educational quality. The space available in a class is further determined by the design and construction which also influence teaching and learning process; and parental choice of such schools. A well designed class quality and construction positively impact on instructional management. The design of learning areas should therefore take into account learners' development needs; provide convenient spaces that will help students to learn. This is because effective use of space and carefully mapped building plans are considered by parents on top of teaching activities to cater for learners' needs and progress. Also learning environment depends on availability of instructional resources in a classroom defines suitability of learning environment and has an influence on learners' achievement. The introduction of FPE over stretched facilities in public schools and especially provision of adequate instructional resources which made parents to opt for private instead of public schools. The study established that effective teaching requires adequate and appropriate facilities, materials and equipment for students to learn in a classroom. Parents would most likely consider schools adequate instructional resources as they facilitate understanding of abstract concepts.

This study confirmed that one of the most important ways in which parents are involved in children's education is through choosing school that is safe School safety embodies another educational priority that parents may consider when making decision on school choice for their children. Parents choose schools for academic reasons and safety measures undertaken by learners, staff, parents and other stakeholders to either minimise or eliminate risky conditions or threats that may cause accidents, bodily injury as well as emotional and psychological distress. A safe and secure school environment facilitates and fosters quality teaching and learning in educational institutions. Schools should provide conditions that allow students to study where parents can feel that their children are safe irrespective of their socio-economic status. The study established that demand for primary schooling in some parts of Kenya is influenced by children security. The study findings confirm comprehensive school safety is fundamental to success and learner achievement. Parents look beyond academic and children security and comfort in school need to 
be emphasized. It is important to note that parents prefer schools that perform the core functions of educating children in a safe environment, irrespective of social class. Therefore, school safety is an integral and indispensable component of the teaching and learning process; and indeed no meaningful teaching and learning can take place in an environment that is unsafe and insecure to both learners and staff.

The study findings also asserted that school social environment besides academic preference influence some parents when choosing a school for their children. The social environment which is defined by teacher-pupil relationship, discipline and the diversity of the school determine choice by parents. To provide students with a good learning environment, schools should make improvements that allow positive social interactions for sustained cohesiveness. The study findings showed that most parents do not feel the need to examine all the alternatives; rather, they wanted to find schools with a strong disciplinary climate and a positive social atmosphere. In practice, parents whether with a college education or not are concerned with school social acceptance and teaching values for consideration in deciding children education. Parents do not base their choice of school on academic quality alone because disciplinary climate and social atmosphere is equally of importance. Parents also give consideration to teacher-student interactions to which some parents who feel that it is important that every student feel respected.

Lastly this study established that parents choose schools that are convenient with the belief that they will provide better educational quality. They believe that pupils attending a school out of immediate environment spend more time on commuting have less time for learning. Parents typically choose a school de facto, according to where they live as a convenience when deciding on children's education. In rural Kenyan most schools do not provide transportation to and from the schools, and to parents here convenience includes issues associated with distance to and from school. Those who are most likely to say that location is important are those who are least likely to have resources necessary to sustain daily transportation to and from a faraway school. Pupils attending a school out of immediate environment spend more time on commuting have less time for learning. The more time a pupil spends on school work, the more learning and stronger willingness to acquire more knowledge and studying in a school outside the zone could have negative impact on learning. In conclusion, school location has an influence on parents' decision on schools and the main consideration is travel distance to school.

\section{Recommendations}

The study recommends that schools should have well designed and constructed classrooms for moderate enrollment and provide adequate instructional resources. Secondly, for meaningful teaching and learning can take place, school environment should be safe and secure. Thirdly, schools should make improvements that allow positive social interactions for sustained cohesiveness. Thirdly, parents should play a positive role in schools nearer home to provide quality education to enable them have their children at schools closer home.

\section{Reference}

Asadullah, M. Niaz \& Chaudhury, N. (2010). Religious schools, social values and economic attitudes: Evidence from Bangladesh. World Development, 38(2), 205-217. http://dx.doi.org/10.1016/j.worlddev.2009.10.014

Ashon-Cudjiw, J. (2009). Making the Right Choice of Second-Cycle Institutions for your BECE Child. Cape Coast: Catholic Mission Press.

Bagley, C., Woods, P. A., \& Glatter, R. (2001). Rejecting Schools: Towards a fuller understanding of the process of parental choice. School Leadership \& Management: Formerly School Organisation, 21(3), 309-325. http://dx.doi.org/10.1080/13632430120074455

Dearden, L., C. Ryan., \& L. Sibieta. (2010). What determines private school choice? A Comparison between the UK and Australia. IFS Working Paper 10/22.

Glennerster R, Kremer M., Mbiti I., \& Takavarasha K. (2011). Access and Quality in the Kenyan Education System. J-PAL, Massachusetts Institute of Technology.

Huisman, J., \& Smits, J. (2009). Effects of Household- and District-Level Factors on Primary School Enrollment in 30 Developing Countries. World Development, $37(1), \quad$ 179-193. http://dx.doi.org/10.1016/j.worlddev.2008.01.007

Johnson, C., \& Bowles, M. T. (2010). Making the Grade? Private Education in Northern India. Journal of Development Studies, 46(3), 485-505. http://dx.doi.org/10.1080/00220380903002939

Kindiki, J. (2009). Effectiveness of communication on student Discipline in Secondary Schools in Kenya. 
Educational Research and Review, 4(5), 63-375.

Lucas, Adrienne \& Isaac Mbiti. (2010). Access, Sorting and Achievement: the Short Run Effects of Free Primary Education in Kenya. SMU Working Paper.

Maphosa, C, \& Mammen, J.K. (2011). How chaotic and unmanageable classrooms have become: Insights into prevalent forms of learner indiscipline in South African Schools. Howard College Campus, Durban 4441, South Africa.

Masese, A., Nasongo, W.J., \& Ngesu, L. (2012). The extent and Panacea for Drug abuse and indiscipline in Kenyan schools. Asian Journal of Medical Sciences, 4(1), 29-36.

Mbiti I. (2010). Access, Sorting and Achievement: the Short-Run Effects of Free Primary Education in Kenya. SMU Working Paper.

Niaz M A, Rupa C., \& Nazmul C. (2012). What Determines Religious School Choice? Theory and Evidence from Rural Bangladesh: IZA DP No. 6883 September 2012.

Oketch M., Mutisya M., \& Sagwe J. (2012). Do poverty dynamics explain the shift to an informal private schooling system in the wake of free public primary education in Nairobi slums? London Review of Education, 10(1), 3-17. http://dx.doi.org/10.1080/14748460.2012.659056

Oketch, M., Mutisya, M., Ngware, M., \& Ezeh, A. C. (2010). Why are there proportionately more poor pupils enrolled in non-state schools in urban Kenya in spite of FPE policy?. International Journal of Educational Development, 30(1), 23-32. http://dx.doi.org/10.1016/j.ijedudev.2009.08.001

Oketch, M.., \& A. Somerset. (2010). Free primary education and after in Kenya: Enrolment impact, quality effects., $\&$ the transition to secondary school. Create Pathways to Access, Research Monograph No. 37, University of Sussex, Falmer.

Omolo, O.D., \& Simatwa, W.M.E. (2010). An assessment of the implementation of safety Policies in public secondary schools in Kisumu East and West Districts. Kenya Educational Research, 1(11), 637-649.

Sarangapani, P. M., \& Winch, C. (2010). Tooley, Dixon and Gomathi on private education in Hyderabad: a reply. Oxford Review of education, 36(4), 499-515. http://dx.doi.org/10.1080/03054985.2010.495465

UNESCO-UIS. (2011). Global education digest 2011: Comparing education statistics across the world. Montreal, Canada: UNESCO Institute for Statistics.

Walker, M., \& Clark, G. (2010). Parental choice and the rural primary school:Lifestyle, locality and loyalty. Journal of Rural Studies, 26(3), 241-149. http://dx.doi.org/10.1016/j.jrurstud.2009.12.002

World Bank (2010). Secondary School Madrasas in Bangladesh: Incidence, Quality., \& Implications for Reform. Bangladesh Development Studies (BDS) Series no 27.

Yi H., \& Chen Y. (2010). An Analysis of Factors Affecting Parents' Choice of a Junior High School. International Journal of Business, Humanities and Technology, 3(2), 39-49. 